\title{
Bench-Scale Studies on Suppressing Ghee Fires with Water Mist
}

\author{
J. QIN ${ }^{1}$, W.K. CHOW', and S.S. HAN ${ }^{2}$ \\ ${ }^{1}$ State Key Laboratory of Fire Science \\ University of Science and Technology of China \\ Hefei, Anhui, China \\ ${ }^{2}$ Research Centre for Fire Engineering \\ Department of Building Services Engineering \\ Area of Strength : Fire Safety Engineering \\ The Hong Kong Polytechnic University \\ Hong Kong, China
}

\begin{abstract}
Ghee fires are difficult to extinguish and easy to re-ignite because the fuel burns at high temperature. This type of fires is different from other traditional Class B fires with flammable liquid fuel, being classified as Class $\mathrm{F}$ fire. In historic buildings using ghee as in temples in Tibet, water mist fire suppression systems are proposed to protect against such fires.

In this paper, small-scale experiments with a cone calorimeter on suppressing ghee fires by water mist were studied. Water mist was generated from a scaled single pressure nozzle. Important parameters on heat release rate per unit area, carbon monoxide concentrations and others were measured under different radiative heat fluxes and system operation conditions.

Experimental results indicated that water mist can suppress ghee fires effectively if designed properly. However, combustion was enhanced once water mist was discharged. Suppression then played a dominating role when water mist of enough volume flux was applied. Fuel cooling was identified to be the key suppression mechanism for ghee fires with a high flashpoint. The water flow rate required is larger than those for controlling typical Class B fires with flammable liquid fuel such as ethanol. Using more water is a concern in protecting historic buildings.
\end{abstract}

KEYWORDS: ghee fire, Class F fire, water mist, suppression, cone calorimeter.

\section{INTRODUCTION}

Ghee is a dairy product in Western part of China such as in Tibet and Gansu provinces e.g. Ref. [1]. It is a kind of white and straw yellow fat made from creamery milk, used for illumination and as food in those areas. It is also used in Buddhism temples such as the Potala Palace. Many lamps are illuminated as 'never extinguishing lights' in the front hall and the Buddha statue.

This gives a potential ignition source and in fact a fire had happened at Lapolen temple (built in 1709) in Gansu in 1985. Adjacent wood structures with the surface layer 'soaked' with ghee were ignited. Flame spread over the material and developed to a big fire.

Such temples are always crowded with people as experienced in many other crowded places in China with similar evacuation problems [2-4]. Further, large amount of combustibles are stored in the temples. Starting a ghee fire would ignite adjacent combustibles to give post-flashover big fires [5]. The historic building might even be totally destroyed as experienced in Korea [6]. Effective fire protection systems must be provided for detecting the fire, giving out early warning signals and extinguishing the ghee fire rapidly. Installing ordinary sprinkler system would discharge too much water and destroy the historic items. Therefore, sprinkler systems are not suitable as discussed in a recent conference on protecting historic buildings in the Asia-Oceania region. Water mist fire suppression systems are proposed for protecting valuable items including historic buildings and other areas as proposed years ago [7]. As only a small amount of water is discharged, suppressing ghee fires should be studied carefully with full-scale burning tests. If the system cannot work as expected, valuable ancient historic buildings will be destroyed [6].

The basic fire suppression mechanisms of a water mist system have been identified [8-11] to be cooling, oxygen displacement and radiant heat blocking. The location and spray momentum of the nozzles, drop size distribution of the discharged water mist, enclosure geometry, obstruction within the space and the fuel 
type are the key factors in determining the performance. In burning ghee with a high flashpoint, fuel cooling is a key fire suppression mechanism. It is important to study the suppression of ghee fires with water mist as there are always concerns on whether water mist can extinguish a fire, and then verify the results by bigger-scale burning tests e.g. Ref. [12].

Heat release rate (HRR) is recognized as one of the important parameters in fire hazard assessment. Fire size, smoke production rate and other fire parameters depend on HRR. Measuring HRR is essential for fire hazard assessment. Bench-scale tests with a cone calorimeter are developed for practical applications [13]. Experiments with a cone calorimeter on small nozzles discharging water mist might be useful to give some rough ideas on the system performance [14]. Small-scale tests further justified $[15,16]$ that the heat release rates measured would indicate whether water mist can suppress the fire. Other information such as burning delay time and gas concentrations before and after discharging water mist can be deduced from the cone data. As most fires under the discharging of extinguishing agents will give incomplete combustion, measuring the HRR by the cone calorimeter would give better estimation for real-scale fire tests with appropriate scaling laws [17] and mathematical models [18].

In this paper, the suitability [15] of using water mist discharged from a small nozzle with characteristics measured to extinguish ghee fires is discussed. Such bench-scale tests can be applied to study the effect of water mist on ghee fires under different thermal radiative fluxes.

\section{EXPERIMENTAL STUDIES}

The burning characteristics of ghee oil with and without water mist discharged were measured by a cone calorimeter. Heat release rate per unit area, burning delay time and gas concentrations were determined. The results were compared with other similar experiments where possible.

Tests were carried out in a glass-walled enclosure of size $0.6 \mathrm{~m}$ by $0.6 \mathrm{~m}$ by $0.7 \mathrm{~m}$ high of the cone calorimeter. The small nozzle was placed inside the cone at an appropriate height to give a spray fully covering the sample below. A steel tray with an area of $100 \mathrm{~mm}$ by $100 \mathrm{~mm}$ and a height of $10 \mathrm{~mm}$ was filled up with the sample ghee oil. The fuel tray was put on a bigger tray fixed over an electric balance to collect the water discharged. Ghee oil was more difficult to ignite than the other flammable liquid fuels. Higher heat fluxes of $30 \mathrm{~kW} \cdot \mathrm{m}^{-2}, 50 \mathrm{~kW} \cdot \mathrm{m}^{-2}$ and $70 \mathrm{~kW} \cdot \mathrm{m}^{-2}$ were applied. These would indicate how ghee would be burnt in a post-flashover fire, and effect of water mist acting at it. Electric spark was used only for igniting the sample and was removed afterward. Re-ignition might occur when water stopped to discharge. All combustion products were collected by the hood for further measurement and analysis. The flow rates of fresh air into the confined space could be varied by the blower of the fan-duct system.

Water mist is generated from a single pressure atomizer with characteristics measured by laser doppler velocimetry or the adaptive phase doppler velocimetry (LDV/APV) system. The velocity and the drop size distributions of the multiphase flow were measured simultaneously. The measuring techniques and the system configuration have been described elsewhere [14,19] and will not be repeated here.

The operating pressure can be varied from $0.2 \mathrm{MPa}$ to $0.7 \mathrm{MPa}$, giving volume flow rates from $68 \mathrm{ml} / \mathrm{min}$ to $134 \mathrm{ml} / \mathrm{min}$. In this experiment, two operating pressures of $0.4 \mathrm{MPa}$ and $0.7 \mathrm{MPa}$ were applied. The resultant water flow rates were $103.5 \mathrm{ml} / \mathrm{min}$ and $134 \mathrm{ml} / \mathrm{min}$ respectively. The cone angle of the nozzle was $90^{\circ}$ and the volume mean diameter of the mist was about $90 \mu \mathrm{m}$. Typical results of the axial velocity and drop size measured at $10 \mathrm{~cm}$ away along the nozzle axis are shown in Figs. 1a and 1b [14-16]. Such characteristic of the water mist would affect the extinguishing capacity. 


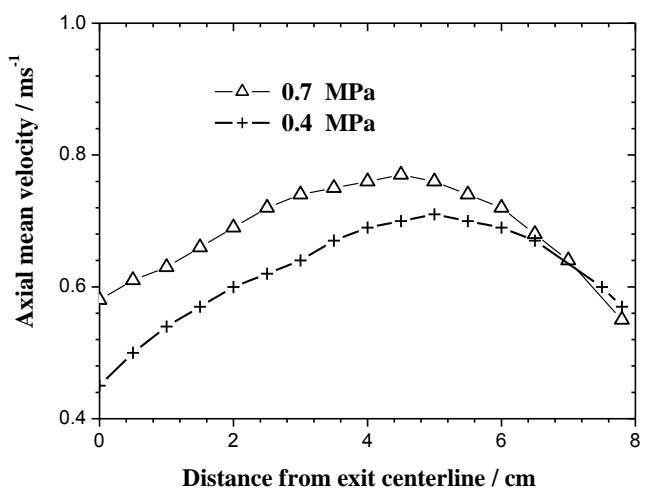

(a)

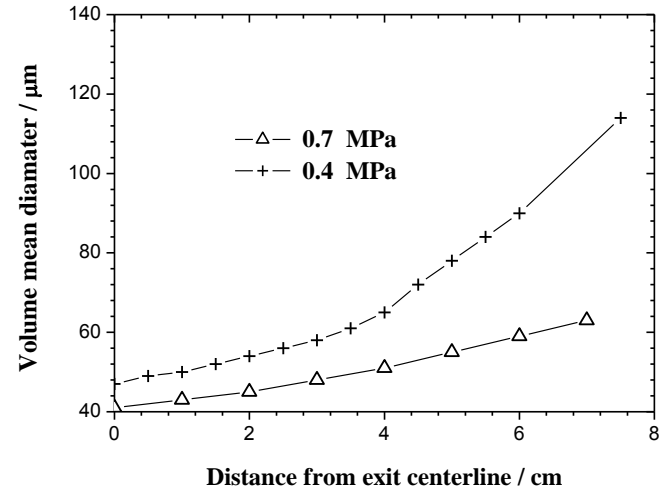

(b)

Fig. 1. Water mist characteristics at $10 \mathrm{~cm}$ below nozzle: (a) mean downward velocity; (b) volume mean diameter.

\section{BURNING TESTS}

A set of preliminary burning tests were performed to investigate the heat release rates. Ghee fires were burnt in three sets of tests labelled as Test 1,2 and 3 under three different radiant heat fluxes of 30,50 and $70 \mathrm{~kW} \cdot \mathrm{m}^{-2}$ respectively.

When the solid ghee sample was exposed to external thermal radiation, it changed to liquid state first. A stable flame then appeared on the surface. The sample was allowed to burn freely until the weight was reduced to a pre-determined value. Water mist was then discharged to extinguish the flame under the two operating pressures described above.

\section{Test 1 with $30 \mathrm{~kW} \cdot \mathrm{m}^{-2}$}

The measured curves of the heat release rate per unit area, oxygen concentration $\left(\mathrm{O}_{2}\right)$, smoke production rate, carbon dioxide concentration $\left(\mathrm{CO}_{2}\right)$ and carbon monoxide concentration $(\mathrm{CO})$ from burning ghee before and after discharging water mist are shown in Figs. 2a to 2e.

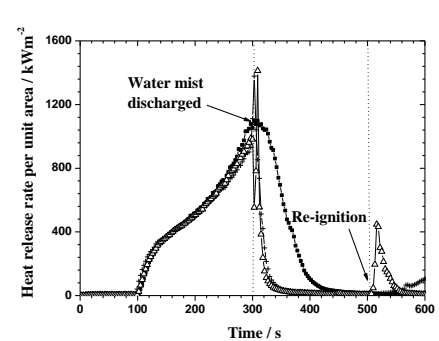

(a)

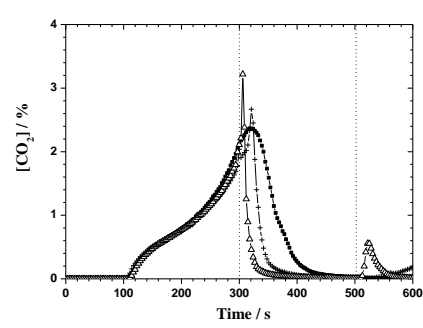

(d)

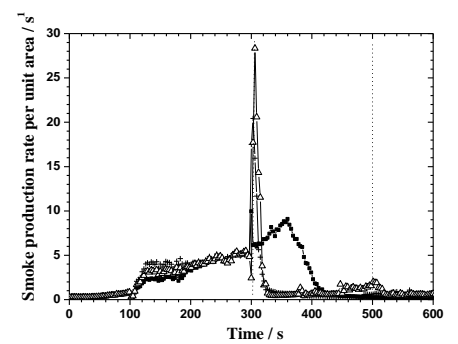

(b)

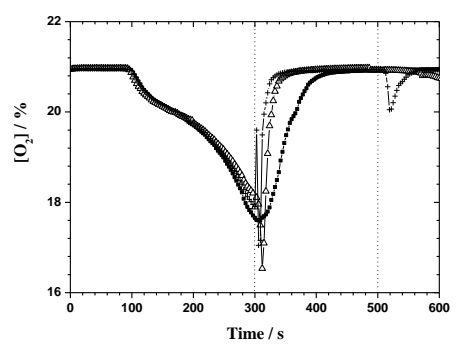

(e)

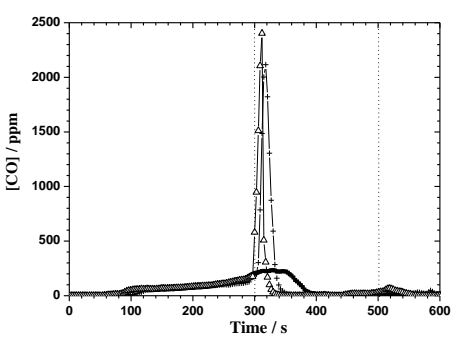

(c)

Fig. 2. Test 1 on ghee fire at $30 \mathrm{~kW} \cdot \mathrm{m}^{-2}:$ (a) heat release rate per unit area; (b) Smoke production rate per unit area; (c) $\mathrm{CO}$ concentration; (d) $\mathrm{CO}_{2}$ concentration; (e) $\mathrm{O}_{2}$ concentration. 
The re-ignition time was measured at the time upon discharging water mist. Water mist was kept discharging over a selected period long enough for extinguishing the fire. The specimen was exposed to the external radiative heat flux for another $200 \mathrm{~s}$, even though the fire appeared to be extinguished. Re-ignition was determined by observing whether a stable flame appeared on the sample surface again. The discharging of water mist would be stopped once the flame was extinguished for the second time.

\section{Test 2 with $50 \mathrm{~kW} \cdot \mathrm{m}^{-2}$}

The procedure was the same as for Test 1 , except that the specimen was exposed to the external radiation for another $48 \mathrm{~s}$ even though the fire appeared to be extinguished.

The curves of the heat release rate per unit area, $\left(\mathrm{O}_{2}\right)$, smoke production rate, $\left(\mathrm{CO}_{2}\right)$ and $(\mathrm{CO})$ with and without water mist discharged at $0.4 \mathrm{MPa}$ and $0.7 \mathrm{MPa}$ are shown in Figs. 3a to 3e.

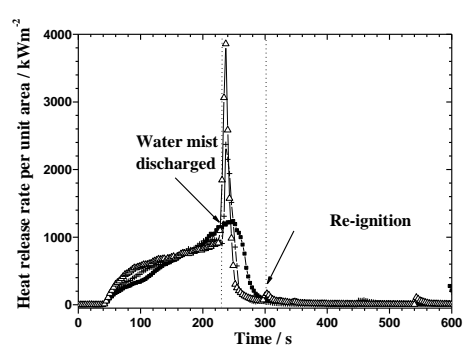

(a)

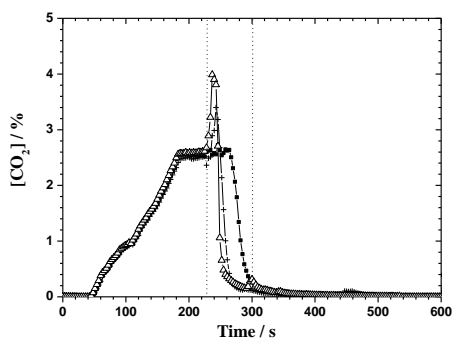

(d)

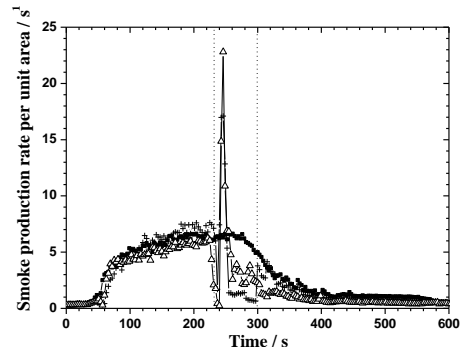

(b)

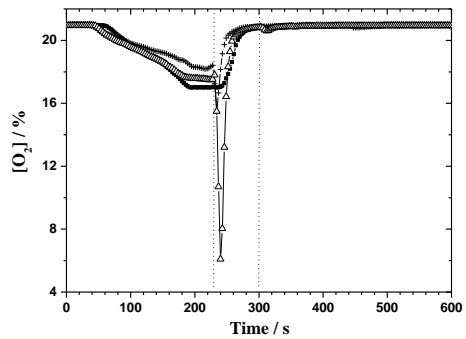

(e)

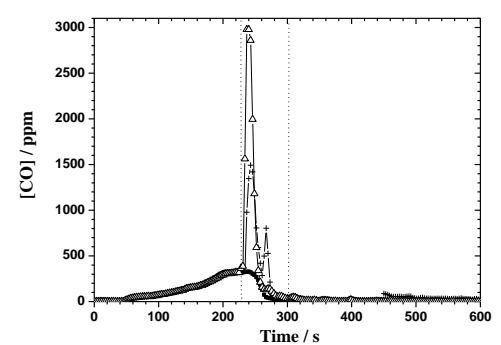

(c)

Fig. 3. Test 2 on ghee fire at $50 \mathrm{~kW} \cdot \mathrm{m}^{-2}$ : (a) heat release rate per unit area; (b) Smoke production rate per unit area; (c) $\mathrm{CO}$ concentration; (d) $\mathrm{CO}_{2}$ concentration; (e) $\mathrm{O}_{2}$ concentration.

\section{Test 3 with $70 \mathrm{~kW} \cdot \mathrm{m}^{-2}$}

The procedure was similar to the above, except that the specimen was exposed to the external radiation for another $95 \mathrm{~s}$ even though the fire appeared to be extinguished.

The curves of the heat release rate per unit area, $\left(\mathrm{O}_{2}\right)$, smoke production rate, $\left(\mathrm{CO}_{2}\right)$ and $(\mathrm{CO})$ with and without discharging water mist at $0.4 \mathrm{MPa}$ and $0.7 \mathrm{MPa}$ are shown in Figs. 4a to 4e. 


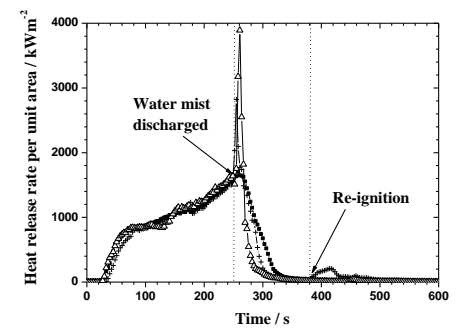

(a)

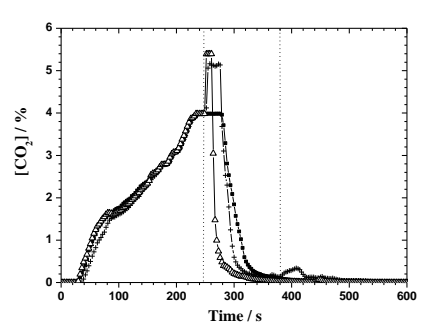

(d)

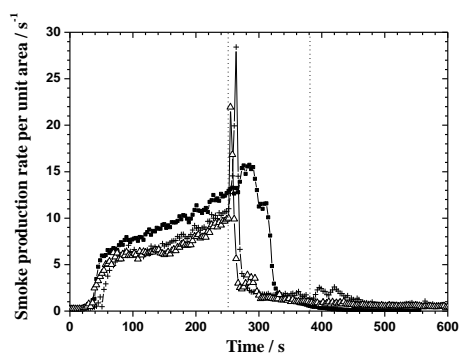

(b)

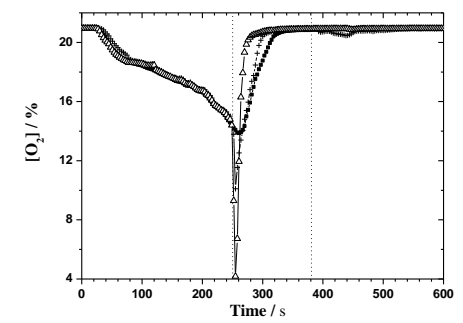

(e)

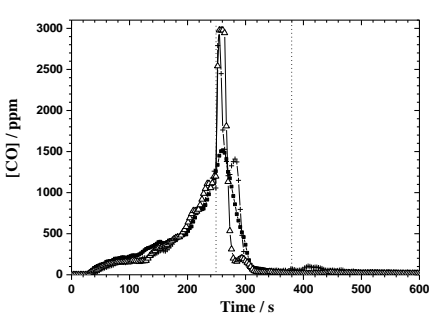

(c)

$$
\begin{aligned}
& -\cdot-\text { No water mist } \\
& -+-0.4 \mathrm{MPa} \\
& -\triangle-0.7 \mathrm{MPa}
\end{aligned}
$$

Fig. 4. Test 3 on ghee fire at $70 \mathrm{~kW} \cdot \mathrm{m}^{-2}:$ (a) heat release rate per unit area; (b) Smoke production rate per unit area; (c) $\mathrm{CO}$ concentration; (d) $\mathrm{CO}_{2}$ concentration; (e) $\mathrm{O}_{2}$ concentration.

\section{RESULTS AND DISCUSSION}

It is observed that the ghee samples were difficult to ignite without applying external thermal radiation. The ignition times were about $100 \mathrm{~s}$ under the heat flux of $30 \mathrm{~kW} \cdot \mathrm{m}^{-2}, 50 \mathrm{~s}$ under $50 \mathrm{~kW} \cdot \mathrm{m}^{-2}$, and about $30 \mathrm{~s}$ under $70 \mathrm{~kW} \cdot \mathrm{m}^{-2}$. Note that the ignition times for ethanol and heptane were less than $1 \mathrm{~s}$. Black smoke would be emitted, suggesting that the combustion is likely to be incomplete.

As shown in Figs. 2 to 4, combustion was enhanced upon discharging water mist.

For Test 1 under an external heat flux of $30 \mathrm{kWm}^{-2}$ and with water mist discharged at a lower operating pressure of $0.4 \mathrm{MPa}$, the maximum heat release rate increased from 1097 to $1378 \mathrm{~kW} \cdot \mathrm{m}^{-2}$. The maximum smoke production rate increased from $3.79 \mathrm{~m}^{-1}$ to $8.51 \mathrm{~m}^{-1}$, the maximum $\mathrm{CO}_{2}$ from $2.37 \%$ to $3.67 \%$, and the maximum CO from $232 \mathrm{ppm}$ to $2116 \mathrm{ppm}$. At a high operating pressure of $0.7 \mathrm{MPa}$, the maximum heat release rate increased up to $1412 \mathrm{~kW} \cdot \mathrm{m}^{-2}$ and the maximum CO to $2403 \mathrm{ppm}$. All values are higher than those before discharging water mist as shown in Table 1.

For Test 2 under an external heat flux of $50 \mathrm{~kW} \cdot \mathrm{m}^{-2}$, the maximum heat release rate increased from $1236 \mathrm{~kW} \cdot \mathrm{m}^{-2}$ to $2372 \mathrm{~kW} \cdot \mathrm{m}^{-2}$ and $3858 \mathrm{~kW} \cdot \mathrm{m}^{-2}$ for the operating pressures of $0.4 \mathrm{MPa}$ and $0.7 \mathrm{MPa}$ respectively. The maximum CO increased from $328 \mathrm{ppm}$ to $1492 \mathrm{ppm}$ and $2978 \mathrm{ppm}$ correspondingly. The heat release rates reached almost the maximum limit of the cone calorimeter as shown in Table 1.

For Test 3 under an external heat flux of $70 \mathrm{~kW} \cdot \mathrm{m}^{-2}$, the maximum heat release rate increased from $1703 \mathrm{~kW} \cdot \mathrm{m}^{-2}$ to $2823 \mathrm{~kW} \cdot \mathrm{m}^{-2}$ and $3889 \mathrm{~kW} \cdot \mathrm{m}^{-2}$ at $0.4 \mathrm{MPa}$ and $0.7 \mathrm{MPa}$ respectively. The maximum CO increased from $1513.8 \mathrm{ppm}$ to $2974 \mathrm{ppm}$ and $2978 \mathrm{ppm}$ correspondingly as shown in Table 1.

It was observed in the above scale modeling tests that discharging water mist would give a bigger flame at the early stage. The heat release rate increased sharply. Extinguishing mechanisms have to be explained by detailed chemical analysis with intermediate chemistry e.g. Ref. [20]. At the moment, it is only possible to propose $[14,19]$ that the liquid drop ebullition increases rapidly. The fast ebullition breaks the stability of the flame and increases the turbulent flow effect to enhance combustion. 
Table 1. Testing results of extinguishing the ghee fires.

\begin{tabular}{|l|c|c|c|c|c|c|c|c|c|}
\hline \multirow{2}{*}{ Parameters } & \multicolumn{2}{|c|}{ Test 1 with 30 $\mathbf{~ k W} \cdot \mathbf{m}^{-2}$} & \multicolumn{2}{c|}{ Test 2 with 50 $\mathbf{~} \mathbf{m} \cdot \mathbf{m}^{-2}$} & \multicolumn{2}{c|}{ Test 3 with 70 $\mathbf{~ W} \cdot \mathbf{m}^{-2}$} \\
\cline { 2 - 10 } & $\begin{array}{c}\text { No } \\
\text { water } \\
\text { mist }\end{array}$ & $\begin{array}{c}0.4 \\
\mathrm{MPa}\end{array}$ & $\begin{array}{c}0.7 \\
\mathrm{MPa}\end{array}$ & $\begin{array}{c}\text { No } \\
\text { water } \\
\text { mist }\end{array}$ & $\begin{array}{c}0.4 \\
\mathrm{MPa}\end{array}$ & $\begin{array}{c}0.7 \\
\mathrm{MPa}\end{array}$ & $\begin{array}{c}\text { No } \\
\text { water } \\
\text { mist }\end{array}$ & $\begin{array}{c}0.4 \\
\mathrm{MPa}\end{array}$ & $\begin{array}{c}0.7 \\
\mathrm{MPa}\end{array}$ \\
\hline $\begin{array}{l}\text { Peak HRR } \\
\left(\mathrm{kW} \cdot \mathrm{m}^{-2}\right)\end{array}$ & 1097 & 1378 & 1413 & 1236 & 2372 & 3858 & 1703 & 2823 & 3889 \\
\hline $\begin{array}{l}\text { Maximum } \\
\text { smoke } \\
\text { production } \\
\left.\text { rate (s }{ }^{-1}\right)\end{array}$ & 9.1 & 20 & 28 & 6.6 & 17 & 23 & 16 & 28 & 22 \\
\hline $\begin{array}{l}\text { Maximum } \\
\mathrm{CO}_{2}(\%)\end{array}$ & 2.37 & 3.67 & 3.22 & 2.75 & 2.84 & 3.98 & 3.98 & 5.16 & 5.39 \\
\hline $\begin{array}{l}\text { Maximum CO } \\
(\mathrm{ppm})\end{array}$ & 232 & 2116 & 2403 & 328 & 1492 & 2978 & 1514 & 2974 & 2978 \\
\hline
\end{tabular}

Oxygen concentration in the flue gas collected by the fan-duct system decreased sharply to a quite low level upon discharging water mist as shown in Figs. 2 to 4. A sudden drop in oxygen concentration was observed under the higher operating pressure to give smaller water droplets as shown in Fig. 1b. Flaring-up of flame was observed to last only for 2 or $5 \mathrm{~s}$. The flame size gradually reduced when water mist was discharged continuously, and the fire was extinguished eventually. The fire can be suppressed faster at higher operating pressures, and then extinguished.

A possible reason for the above is due to the evaporative expansion of water droplets, giving a better mixing of air and the fuel vapor. Higher operating pressures will give finer water mists, resulting in combustion enhancement, though only lasting for a short duration. Further, finer water vapor produced might affect the chain reactions to suppress the formation of soot as proposed before [16].

If the discharging of water mist was stopped immediately when the visible flame was extinguished, the ghee would be re-ignited within several minutes when the external heat flux was still present. Re-ignition occurred at $200 \mathrm{~s}, 48 \mathrm{~s}$ and $95 \mathrm{~s}$ for the external radiant heat fluxes of 30,50 and $70 \mathrm{~kW} \cdot \mathrm{m}^{-2}$ respectively, as shown in Figs. 2 to 4.

The fuel temperature was high upon ignition due to higher heat fluxes were required, but decreased after water mist application. This suggested that fuel cooling is a key suppression mechanism for fuels with a high flashpoint, rather than 'flame cooling' and 'oxygen displacement'. Therefore, the required water flow rate is larger than those for Class B flammable liquid fuel fires such as ethanol where extinguishment is mainly through flame cooling and oxygen displacement.

In this study, only bench-scale tests on suppressing ghee fires with water mist were reported. Water mist discharged should have sufficient momentum to overcome the upward plume motion in order to deliver to the fuel surface. Full-scale burning tests [12] are required to confirm the performance of the system design. Detailed extinguishing mechanisms have to be explained by combustion chemistry [20].

\section{SMOKE HAZARDS}

Fire hazards due to toxic gases and smoke produced in a ghee fire are another concern. As shown in Figs. 2 to 4 , CO increased rapidly up to the dangerous value $3000 \mathrm{ppm}$ after discharging water mist. Since the oxygen supply rate depended on the exhaust fan rate, enhanced combustion effect due to water mist application would be less efficient. As a result, more carbon monoxide was produced. These results are supported by measuring $\mathrm{O}_{2}$ and $\mathrm{CO}$ in the reaction zone with gas sampling techniques as for methane flame [21,22]. More attention should be paid on suppressing ghee fires with water mist in a confined space.

As shown in Figs. 2 to 4, the smoke production rate per unit area for the ghee fires decreased sharply after discharging water mist. The value then increased before the flame was extinguished. Water mist might be able to scrub the black smoke produced from the ghee fire through absorbing soot and other gases soluble in water. Smoke damage would be reduced, and that would be more beneficial to the occupants and the valuable properties in those historic buildings. 
A poorly designed water mist system would give a more hazardous smoking environment. If the flame can be extinguished in a short time by discharging water mist at an adequate flow rate, the total production rate of carbon monoxide would be reduced rapidly to give a less hazardous environment. As discussed in the literature [8-11], a key factor is to operate the system at higher pressure so that water mist of adequate momentum can be discharged to cool the fuel surface.

\section{CONCLUSIONS}

Ghee fires are difficult to extinguish and easy to re-ignite because the fuel burns at higher temperature. The fire is quite different from the conventional Class B flammable liquid fuel fires. Water mist fire suppression systems are suggested to protect historic buildings such as temples using ghee. Bench-scale tests on assessing the performance of water mist were carried out. Combustion would be enhanced at the early stage upon discharging water mist onto the ghee fire. However, suppression would play a dominating role when water mist of adequate flow rate was applied. Fuel cooling is identified to be the key suppression mechanism for ghee with a high flashpoint. Therefore, the required water flow rate would be larger than those for suppressing conventional flammable liquid fuel fires through flame cooling and oxygen displacement.

The smoke production rate for the ghee fires decreased sharply immediately after discharging water mist and then increased before the flame was extinguished. A large volume of black smoke was produced. The concentrations of carbon monoxide increased sharply after discharging water mist.

The ghee specimen can be re-ignited even though the fire appeared to be extinguished, if exposed to the external radiation for several minutes. Therefore, water mist can only suppress ghee fires effectively with proper design and operation. More water with a longer discharging time might be required. This is a concern in protecting valuable historic buildings. Combining scale modeling studies with scaling law [17] and mathematical models [18] would be helpful to develop workable water mist systems. Full-scale fire tests [12] should then be carried out to confirm the results.

\section{ACKNOWLEDGMENT}

This work was jointly supported by the China NKBRSF (Project No. 2001CB409600) and The Hong Kong Polytechnic University (PolyU). The authors would like to thank Mr. Angus Cheng for his help in carrying out the experiments at PolyU.

\section{REFERENCES}

[1] http://www.cctv.com/geography/shijieyichan/sanji/budalagong.html. Accessed 14 February 2011.

[2] Chow, W.K., and Ng, C.M.Y. (2008) Waiting Time in Emergency Evacuation of Crowded Public Transport Terminals, Safety Science 46(5): 844-857. http://doi.dx.org/10.1016/j.ssci.2007.01.015

[3] Jiang, C.S., Deng, Y.F., Hu C., Ding, H., and Chow, W.K. (2009) Crowding in Platform Staircases of a Subway Station in China during Rush Hours, Safety Science, 47(7): 931-938. http://doi.dx.org/10.1016/j.ssci.2008.10.003

[4] Zhuang, L., Wang, F.L., Sun, X.Q., Lu, S.X. (2006) Investigation and Analysis of Fire Hazards of the Potala Palace, Fire science and Technology- In Chinese, 25(3): 307-340.

[5] Society of Fire Protection Engineers - Taiwan Chapter, Proceedings of the 2010 Exchange Meeting for Society of Fire Protection Engineers Asia-Oceania Chapters-Fire Risk Analysis and Response Plans Regarding Heritages and Historical Buildings, Taipei, Taiwan, 28-29 October 2010.

[6] Roh, S-K., Ham, E-G., Kim, J-S., Kim, K-S., Kim, W-S., Jeong, K-S., Nam, D-G., “A Study on the Combustion Characteristics of Korean Traditional Wooden Structure Buildings Under Fire Conditions", Proceedings of the $8^{\text {th }}$ Asia - Oceania Symposium on Fire Science and Technology, Melbourne, Australia, 7-9 December 2010.

[7] Hadjisophocleous, G.V., An, M., Costa, V.A.F., and Sousa, A.C.M. (2001) Fire Suppression Using Water Mists - A Numerical Model, Journal of Mechanical Engineering, 47(8): 424-434. 
[8] Jones, A., and Nolan, P.F. (1995) Discussion on the Use of Fine Water Sprays or Mists for Fire Suppression, J. Loss Prev. Proc. Ind., 8(1): 17-22. http://doi.dx.org/10.1016/0950-4230(95)90057$\underline{\mathrm{V}}$

[9] Mawhinney, J.R., and Richardson, J.K. (1997), A Review of Water Mist Fire Suppression Research and Development - 1996, Fire Technology 33(1): 54-90. http://doi.dx.org/10.1023/A:1015322428719

[10] Liu, Z., and Kim, A.K. (2000), A Review of Water Mist Fire Suppression Systems - Fundamental Studies, Journal of Fire Protection Engineering 10(3): 32-50. http://doi.dx.org/10.1177/104239159901000303

[11] Mawhinney, J.R., "Water Mist Fire Suppression Systems", Fire Protection Handbook (2008 ed), A.E. Cote (ed.), National Fire Protection Association, Quincy, Mass, USA, 2008, Chapter 16.8.

[12] Chow, W.K., Gao, Y., Dong H., Zou G., and Meng L. (2003), Will Water Mist Extinguish a Liquid Fire Rapidly? Architectural Science Review, 46(2): 139-144.

[13] ASTM E 1354 - 04a, Standard Test Method for Heat and Visible Smoke Release Rates for Materials and Products Using an Oxygen Consumption calorimeter, ASTM International, West Conshohocken, PA, USA, 2004.

[14] Yao, B., Fan, W.C., and Liao, G.X. (1999), Interaction of Water Mists with a Diffusion Fire in a Confined Space, Fire Safety Journal 33(2): 129-139. http://doi.dx.org/10.1016/S03797112(99)00020-X

[15] Chow W.K., Qin J. and Han S.S. (2005), Bench-scale Tests on Controlling Plastic Fires by Water Mist, Chem. Eng. Technol., 28(9): 1041-1047. http://doi.dx.org/10.1002/ceat.200500063

[16] Wang, X.S., Chow, W.K., Wu M., (2008-2009) A Review on Determining Water Spray Droplet Characteristics by Laser Techniques, Journal of Applied Fire Science 18(3): 211-239. http://doi.dx.org/10.2190/AF.18.3.b

[17] Quintiere, J.G., (1989) Scaling Applications in Fire Research, Fire Safety Journal 15: 3-29. http://doi.dx.org/10.1016/0379-7112(89)90045-3

[18] Li, Y.F., and Chow, W.K. (2008) Study of Water Droplet Behavior in Hot Air Layer in Fire Extinguishment, NFPA - Fire Technology 44: 351-381. http://doi.dx.org/10.1007/s10694-007$\underline{0036-2}$

[19] Qin, J., Liao, G.X., Wang, X.S, Tao, B. (2001) Measurement of Flow Field of Water Mist by 3D LDV, Chin. J. Quant. Electronics-In Chinese, 18(3): 281-284.

[20] Jiang, Z., Chow, W.K., Tang, J., and Li, S.F., (2004) Preliminary Study on the Suppression Chemistry of Water Mists on Poly(methyl methacrylate) Flames, Polymer Degradation and Stability, 86(2): 293-300. http://doi.dx.org/10.1016/j.polymdegradstab.2004.03.024

[21] Atreya, A., Crompton, T. and Suh, J., "Basic Research on Fire Suppression", Annual Conference of Fire Research: Abstracts, NISTIR 5499, National Institute of Standard and Technology, Gaithersburg, MD, USA, 1994, pp. 177-180.

[22] Downie, B., Polymeropoulos, C. and Gogos, G., (1995) Interaction of a Water Mist with a Buoyant Methane Diffusion Flame, Fire Safety Journal, 24(4): 359-381. http://doi.dx.org/10.1016/0379-7112(95)00029-1 